\title{
Is dry eye an environmental disease?
}

\section{O olho seco é uma doença relacionada a exposição ambiental?}

\author{
Monica Alves ${ }^{1}$, Priscila Novaes ${ }^{2}$, Monica de Andrade Morraye ${ }^{3}$, Peter Sol Reinach ${ }^{1}$, Eduardo Melani Rocha ${ }^{1}$
}

\begin{abstract}
Previous studies have revealed that eye contact with either air pollutants or adverse indoor and/or outdoor environmental conditions can affect tear film composition and ocular surface components. These effects are mediated by selective binding of the environmental agents to ocular surface membrane receptors, leading to activation of pro inflammatory signaling pathways. The aim of the current review was to examine the published evidence associated with environmental factors and ocular surface disease and dry eye. Specifically, the reader will appreciate why it is possible to refer to them as mediators of Environmental Dry Eye Disease (EDED), a singular clinical entity inside DED context, directly caused by pollutants and/ or adverse climatic conditions. The indicators and clinical findings are described along with EDE differential diagnosis in its acute and the chronic phases. Based on strong existing evidence of clinical reports and epidemiological observations regarding DED and environmental factors we conclude that there is a straight cause-and-effect relationship between ambient stresses and DED. Internationa standards and web-based tools are described for monitoring worldwide environmental conditions referring localities and populations susceptible to EDED. This information is beneficial to health providers to pinpoint the individuals and predisposed groups afflicted with DED. Such insights may not only improve the understanding and treatment of DED but also help to identify the contributing factors and lower the frequency and progression of EDED.
\end{abstract}

Keywords: Dry eye syndromes; Lacrimal apparatus diseases; Environmental illness; Environmental pollutants/adverse effects

\section{RESUMO}

Diversos estudos têm demostrado que o contato ocular com poluentes ambientais afeta a composição do filme lacrimal e de estruturas da superfície ocular. Tais efeitos são mediados pela ligação de agentes ambientais com receptores na superfície ocular, levando a ativação de mediadores pró inflamatórios. Esta revisão propõe uma avaliação das evidências publicadas, que associam fatores ambientais as doenças de superfície ocular e ao olho seco. O leitor compreenderá que é possivel inferir olho seco ambiental como uma entidade singular dentro do contexto da doença olho seco, diretamente causado pela exposição a poluentes e/ou condições climáticas adversas. Serão descritos os indicadores e achados clínicos, assim como o diagnóstico diferencial das fases aguda e crônica. A avaliação de relatos clínicos e observações epidemiológicas demonstra uma forte associação entre olho seco e fatores ambientais. O conhecimento sobre parâmetros internacionais e ferramentas de monitorização das condições ambientais no mundo, permite identificar localidades e populações mais suceptívies ao olho seco ambiental e pode auxiliar na identificação de indivíduos acometidos e grupos predispostos. E desta forma, melhorar o entendimento e tratamento dessa condição, diminuir os fatores associados, sua frequência e progressão.

Descritores: Síndromes do olho seco; Doenças do aparelho lacrimal; Doença ambiental; Poluentes ambientais/efeitos adversos.

\section{INTRODUCTION}

Epidemiological studies have indicated increasing incidence of dry eye disease (DED) in the worldwide population ${ }^{(1-3)}$. This common ocular condition has multiple causes, which are not entirely understood. The emerging awareness that environmental factors can contribute to DED is supported by some recent studies and reflects differences in cultural traditions and exposure to unfavorable working conditions. In these groups, the impact of environmental factors in DED demands further characterization to develop strategies to reduce its incidence ${ }^{(4,5)}$. Due to the apparent relationship between the aforementioned environmental influences and DED, this disease can be better defined by delineating Environmental Dry Eye Disease (EDED) as a clinical subtype of DED.

We summarize herein our current understanding of environmental causes for DED. However, this review does not deal with some other relevant exogenous factors, such as usage of drugs and alcohol as their effects were recently well addressed ${ }^{(6,7)}$. In addition, we omitted the effect of nutritional factors on DED, which due to its extension and complexity deserves an entire review.
EDED is not only an association between environmental conditions and well-defined ocular surface inflammatory conditions, it is considered as a clinical subtype of DED (Table 1). In EDED cases, the inflammatory conditions and ocular discomfort are followed by changes in tear film composition volume and osmolarity, which may persist even after the individuals are no longer exposed to the related environmental factors. In one example of EDED, following an environmental accidence the symptoms persisted for two years ${ }^{(8-10)}$.

EDED is strongly influenced by one or more environmental factor. Additionally, improper diagnosis of toxic keratoconjunctivitis, solar keratitis, allergic keratoconjunctivitis or some other types of ocular surface disease can contribute to EDED. These conditions show similar symptoms and environmental factors on the existing condition further leading to EDED. It is likely that some overlap exists among the mediators of these diseases. This review focuses on some unique environmental factors distinctive of EDED (Figure 1).

EDED gained relevance based on the recognition that environmental factors can be deleterious to human health and contributes to $\mathrm{DED}^{(11,12)}$. The impact of the environment in the pathophysiology
Submitted for publication: April 15, 2014

Accepted for publication: June 4, 2014

Study conducted at Departamento de Oftalmologia, Otorrinolaringologia e Cirurgia de Cabeça e Pescoço Universidade de São Paulo - Ribeirão Preto (USP-RP).

Universidade de São Paulo, Ribeirão Preto, SP, Brazil

2 Universidade de São Paulo, São Paulo, SP, Brazil

${ }^{3}$ Universidade de Franca, Franca, SP, Brazil
Funding: No specific financial support was available for this study.

Disclosure of potential conflicts of interest: None of the authors have any potential conflicts of interest to disclose.

Corresponding author: Monica Alves. Department of Ophthalmology, Otorhinolaryngology and Head $\&$ Neck Surgery. Faculty of Medicine of Ribeirão Preto, University of São Paulo. Av. Bandeirantes, 3.900 - CEP 14049-900 - Ribeirão Preto, SP, Brazil - E-mail: monicalves1@uol.com.br 
Table 1. Differential diagnosis of Environmental Dry Eye Disease

\begin{tabular}{|c|c|c|}
\hline Disease & Causes & Clinical features \\
\hline Solar keratitis ${ }^{(19)}$ & UV exposure & Keratosis of exposed skin, burning sensation, redness, punctate keratitis \\
\hline Allergic keratoconjunctivitis ${ }^{(10)(20)}$ & Allergy & History of allergy, redness, itching, swelling \\
\hline Floppy eyelid syndrome ${ }^{(21)}$ & Rubbery, redundant upper tarsus & Lid eversion with minimal pressure. Redness, papillary conjunctivitis \\
\hline Corneal hiperalgesia(22) & $\begin{array}{l}\text { Up regulated nocioreception triggered by } \\
\text { corneal damage }\end{array}$ & $\begin{array}{l}\text { Disparity between signs and symptoms, corneal sensory deficit and } \\
\text { decreased sensory nerve population }\end{array}$ \\
\hline Ligneous conjunctivitis (23) & $\begin{array}{l}\text { Impaired mucosal wound healing and fibrosis due } \\
\text { to plasminogen deficiency }\end{array}$ & Chronic membranous conjunctivitis triggered by local trauma \\
\hline Mucous fishing syndrome ${ }^{(24)}$ & Excess of mucous manipulation & $\begin{array}{l}\text { Secretion, redness, and foreign body sensation along with } \\
\text { signs of epithelial trauma due to discharge of mucus }\end{array}$ \\
\hline Pseudopemphigoid(25) & History of topical drug exposure. & Redness, tearing, itching, and progressive fibrosis of conjunctiva \\
\hline Chronic blepharitis(26) & $\begin{array}{l}\text { Dysfunction of lipid production and secretion } \\
\text { and epithelial metaplasia }\end{array}$ & $\begin{array}{l}\text { Lid erythema, greasy crusting secretion. Redness and irritation of the eye } \\
\text { Seborrhea in other sites of the body }\end{array}$ \\
\hline Stevens-Johnsons Syndrome ${ }^{(27)}$ & $\begin{array}{l}\text { Autoimmune disease triggered by drug or } \\
\text { microorganism }\end{array}$ & $\begin{array}{l}\text { Acute: systemic epithelial bullous swelling. Chronic: ocular surface fibrosis, } \\
\text { corneal vascularization, and recurrent epithelial defect }\end{array}$ \\
\hline Toxic keratoconjunctivitis ${ }^{(28)}$ & $\begin{array}{l}\text { Toxic agent traumatic, iatrogenic or factitious } \\
\text { contact with ocular surface }\end{array}$ & $\begin{array}{l}\text { Variable, depending on agent and time. Commonly, acute epithelial swelling, } \\
\text { redness, and tearing }\end{array}$ \\
\hline
\end{tabular}

of DED has been studied and confirmed in animal models of human DED $^{(13-15)}$.

As indicated, a healthy and pain-free ocular surface depends on identifying and eliminating factors that cause ambient humidity, airflow and purity, and temperature to intolerable levels. Such an undertaking is needed to preserve tear film qualities commensurate with ocular surface health. This is essential to sustain sufficient corneal refractive power, visual acuity, and ocular comfort $(5,16,17)$.

A desiccating environment can lead to increase in tear film evaporation and/or decline in its turn over and clearance. These initial events lead to exposure of the ocular surface to hazardous environmental elements that trigger or exacerbate EDED symptoms. Clinical findings have shown that increased numbers of people are affected by EDED because of exposure to environmental factors (Figure 2).

Our purpose herein is to provide a critical appraisal of the clinical and epidemiological evidence indicating that DED is influenced by environmental factors. Secondly, we delineate EDED as a single clinical entity with a unique set of symptoms and clinical findings different from that of either DED or other diseases, such as Sjögren's syndrome, diabetes mellitus or drug induced, allergic conjunctivitis, toxic or irritative conjunctivitis, and actinic keratitis. Moreover, we will describe standard tools used to monitor environmental conditions and discuss their relevance in EDED epidemiological studies. This review enables the health care providers and researchers to identify the environmental risk factors associated with the development and progression of EDED. This initiative intends to help future studies to improve our understanding and care for this possibly common and complex disease.

Environmental Dry Eye Disease (EDED) can be considered a clinical entity that qualifies the definition of DED (18). The most relevant causal factor is environmental exposure, such as pollutants and/or adverse climate. On the other hand, causative factors related to systemic diseases (endocrine, metabolic, nutritional, autoimmune, genetic, viral or neurologic), anti-cholinergic, adrenergic or other drug-related side effects are considered as exclusion factors to maintain EDED as a distinct disease entity within the DED envelope.

EDED differential diagnosis comprises the entities shown in table 1.

Possible non-environmental factors or undiagnosed causes of DED were also considered as differential (for example a suspected Sjögren's syndrome was not investigated to fulfill the criteria). From this perspective, diseases that were labeled as "pollution keratoconjuncitivitis," "computer vision syndrome," and other environmentally related encounters, due to DED clinical presentation would be defi-

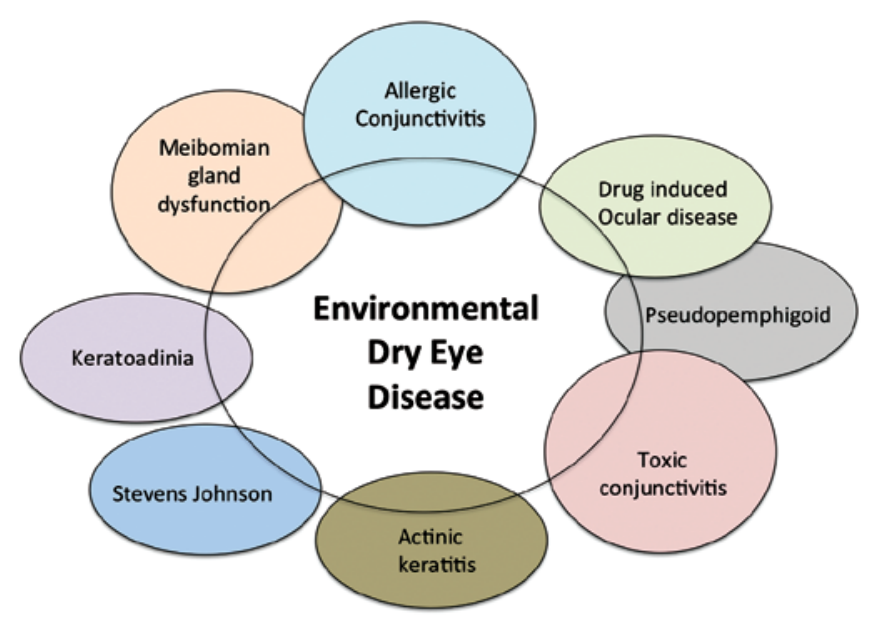

Figure 1. Illustration of conditions whose signs and symptoms may overlap with environmental dry eye disease clinical presentation.

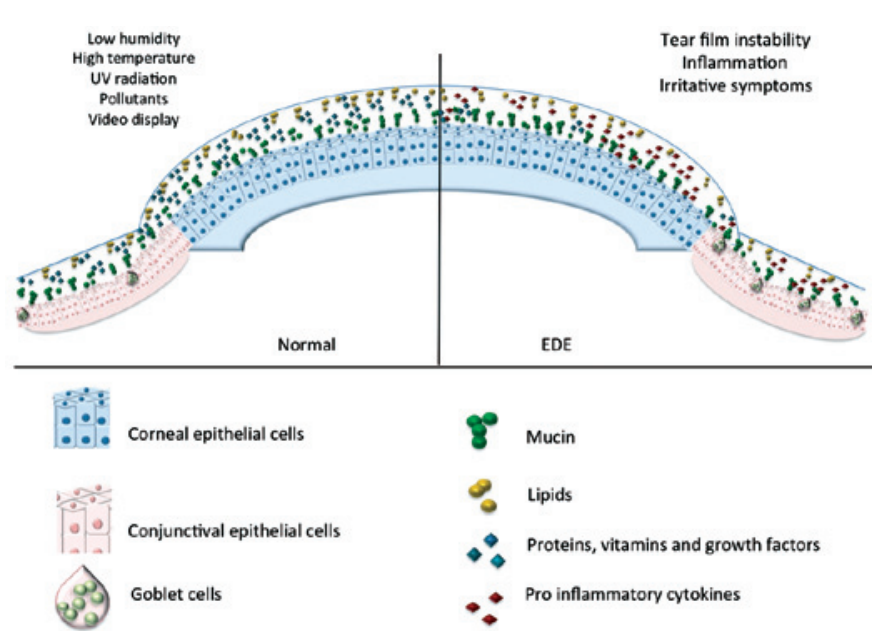

Figure 2. Environmental factors that influence tear film and ocular surface indoors and outdoors (air borne particles, air flow, temperature, ultraviolet rays). 
ned as EDED ${ }^{(29-31)}$. Patients can be afflicted with EDED due to exposure to a variety of environmental stresses. Conditions that elicit this disease are patient dependent $t^{(32,33)}$. To establish a minimal normative classification for research and clinical purposes and therapeutic measures, the following environmental factor categories are included:

Indoors: closed ambient like office settings, such as variations in airflow, humidity, time in front of computer and other video displays, and exposure to toxic elements (for example offices, health care facilities, poorly ventilated confinements such as subway stations and other employment areas).

Outdoors: exposure to open areas with extreme temperatures, gases and/or air suspended particles in the desiccating wind, intense UV exposure, agricultural usage of state of the art technology and mechanization, petrochemical industries, urban traffic, and other polluted environments.

Although the clinical signs of EDED can be similar among individuals exposed to either indoor or outdoor environmental factors, the detection preventive, and therapeutic methods are specific for each of these different settings. Additionally, the combined exposure to indoor and outdoor factors is also plausible.

Since the 1960's, exposures to environmental factors such as air pollution had been correlated with ocular surface irritation, resulting in symptoms of hyperemia, swelling, tearing, and dry eye sensation ${ }^{(34)}$.

EDED patients present a broad range of symptoms, the most common being sorrow eyes and visual fatigue. The scores obtained from structured questionnaires have been used for the analysis. One of them is the Ocular Symptom Disease Index (OSDI), which evaluates DED severity rather than EDED(35-37). In order to correlate ocular surface related DED signs with environmental activities, an interesting activity log for DED was recently developed and tested in patients. However, individual differences in pain perception or exposure to environmental hazards in DED initiation were not evaluated(5).

EDED is distinguishable from aforementioned, because it is chronic and is associated with environmental factors. Such clinical findings are identifiable by the clinician/researcher investigating the disease. EDED identification stems from controlled observations about pollution-induced ocular alterations, such as blinking rate, tear film break up time (TFBUT), and corneal epithelia damage ${ }^{(38,39)}$.

Tear film instability is a consistent finding in studies that showed an association between air pollution and ocular surface damage ${ }^{(37,40-42)}$ Such an effect compromises the corneal epithelial barrier function resulting in corneal and conjunctival epithelial chronic injury and inflammation.

A recent study has described a possible early adaptive response to air pollution in which increased levels of air pollution reduce tear film osmolarity and conjunctival goblet cell density ${ }^{(8,37)}$. This negative correlation is indicative of EDED whereby increase in air pollution and/or desiccation are thought to have an early reactive phase followed by a chronic adaptive/metaplastic phase. Clinical findings can help to identify the contributions of exposure time to EDED progression (Table 2).

Table 2. Clinical findings in early and chronic phases of Environmental Dry Eye Disease, compared with non-exposed individuals ${ }^{(8,37,41)}$

\begin{tabular}{lcc}
\hline Clinical findings & Early reactive phase & Chronic adaptive phase \\
\hline Symptoms & Variable & Low \\
Tear film osmolarity & Lower & Higher \\
Hyperemia & Present & Present \\
MGD & Present & Present \\
Schirmer test & High & Low \\
TFBUT & Lower & Lower \\
Vital staining & Normal & Altered \\
Conjunctival Goblet cells & Higher number & Lower number
\end{tabular}

On the other hand, it is possible that other clinical signs may be associated with the disease, complicating a definitive diagnosis. For example, larger lid opening, lower mucous production, slower blinking rate, and reduced tear film clearance. Such symptoms may be found in different individuals afflicted with different degrees of EDED severity even if they are exposed to the same adverse environmental factors. Future studies are needed to characterize and weigh the individual contributions of commonly observed environmental factors to EDED progression.

\section{EPIDEMIOLOGY OF DRY EYE RELATED TO ENVIRONMENTAL FACTORS}

Outdoor EDED risk factors include exhaust emissions from automobiles and industrial facilities common in densely populated cities ${ }^{(43,44)}$. Furthermore, occupational hazards related to large-scale agriculture and sugar cane processing can lead to exposure to gases, particulate matter, UV exposure, and altered microbiota ${ }^{(45,46)}$.

On the other hand, indoor environmental conditions involving low humidity, excessive use of video display units (VDU), and high levels of $\mathrm{CO}_{2}$ can be equally threatening to ocular surface health ${ }^{(4,47-49)}$.

Case-control studies confirm the cause-effect relationship between the indoor or outdoor environmental conditions and the irritant symptoms in exposed individuals $\mathrm{s}^{(49,50)}$. Also, the individual risk factors are similar to those in other populations afflicted with other types of $D E D^{(51)}$. They include aging, females, allergic or autoimmune conditions, and usage of contact lenses (4, $48,52-55)^{\text {. }}$

Part of the confusion that persists about EDED recognition is because individuals exposed to high air pollution levels are often at greater risk of developing allergies and present more symptoms ${ }^{(55)}$. Moreover, there is also an association between increase in air pollution and autoimmune diseases, such as rheumatoid arthritis and systemic lupus erythematous ${ }^{(56-58)}$. There is also speculation about the existence of an "urban allergy syndrome" (Table 3)(59). Such individuals have a higher incidence of ocular surface inflammation and DED.

Although the acceptable levels of pollutants are established by national and world agencies (see below), the cut-off limits of the most harmful pollutants and environmental risk factors to the ocular surface capable to induce EDED are unknown. If more than one factor is involved, depending upon their characteristics they may interact at lower threshold values and induce EDED. Accordingly, the detrimental effects of environmental toxic agents on EDED epidemiology are not entirely understood $(43,44,60-62)$.

The impact of urban pollution and environmental toxins on the ocular surface has been evaluated in a few case-control studies. These studies reported a high incidence of ocular discomfort, tear film instability, and ocular surface changes among individuals lived in highly polluted cities of the world (Table 4).

Two studies in New Delhi compared the groups of individuals living inside and outside the metropolitan area ${ }^{(63)}$. A higher frequency of EDED findings with TFBUT $<10$ seconds, Schirmer Test (ST) $<10 \mathrm{~mm}$, and low lysozyme levels in tears were reported among the individuals living within the metropolitan area. The decline in these values correlate with increase in pollutant levels in the metropolitan area compared with the rural area. Another study on 500 volunteers documented

\section{Table 3. Individual and environmental risk factors for Environmental} Dry Eye Disease (EDED)

\begin{tabular}{ll}
\hline \multicolumn{1}{c}{ Risk factors for EDED } \\
\hline Individual & $\begin{array}{l}\text { Age, female gender, contact lens usage, lengthy exposure to the } \\
\text { hazards (video display, air conditioning), allergies, eye make up, } \\
\text { blinking frequency }\end{array}$ \\
Environmental & $\begin{array}{l}\text { Humidity, temperature, high levels of pollutants (particulate matter, } \\
\mathrm{CO}_{2,} \mathrm{NO}_{2} \text {, elemental carbon), regions with heavy automobile } \\
\text { transport, pollutant industrial activity, subway stations }\end{array}$ \\
\hline
\end{tabular}


Table 4. Effects of pollution on ocular surface: summary of epidemiological studies

\begin{tabular}{|c|c|c|c|c|c|c|}
\hline Author & Year & Study design & Local & $\mathbf{n}$ & Endpoints & Conclusions \\
\hline Versura $^{(44)}$ & 1999 & Case-control & Italy & 200 & $\begin{array}{c}\text { Schirmer } \\
\text { Ferning } \\
\text { BUT } \\
\text { Impression cytology } \\
\text { Inflammation }\end{array}$ & $\begin{array}{c}\text { Abnormal values of BUT 32\%, } \\
\text { Schirmer 40\%, and Ferning 45\%. } \\
\text { Abnormal impression cytology: } \\
\text { odds ratio } 2.66 \text { (IC95\% 1.42-5.02) } \\
\text { Inflammation: odds ratio } 2.27 \\
\text { (IC95\% 1.14-2.16) }\end{array}$ \\
\hline Gupta ${ }^{(63)}$ & 2002 & Case-control & New Delhi, India & 400 & $\begin{array}{c}\text { BUT } \\
\text { Schirmer } \\
\text { Lysozyme activity }\end{array}$ & BUT (odds ratio: 5.63, IC 95\% 2.76-11.46) \\
\hline Saxena ${ }^{(43)}$ & 2003 & Case-control & New Delhi, India & 500 & $\begin{array}{l}\text { Symptoms } \\
\text { Lysozyme } \\
\text { Rose bengal } \\
\text { BUT } \\
\text { Schirmer }\end{array}$ & $\begin{array}{c}\text { Positive correlation with symptoms } \\
\text { BUT and Schirmer were lower in } \\
\text { study group } \\
\text { No difference in lysozyme } \\
\text { and rose bengal }\end{array}$ \\
\hline Novaes $^{(8)}$ & 2007 & Case-control & Sao Paulo, Brazil & 29 & Impression cytology & $\begin{array}{l}\text { Increased goblet cells density in } \\
\text { individuals exposed to higher levels of } \mathrm{NO}_{2}\end{array}$ \\
\hline Novaes ${ }^{(41)}$ & 2010 & Series of cases & Sao Paulo, Brazil & 55 & $\begin{array}{c}\text { Symptoms } \\
\text { BUT } \\
\text { Schirmer }\end{array}$ & $\begin{array}{c}\text { Positive correlation with symptoms } \\
\text { Higher incidence of MGD, BUT weak } \\
\text { correlation and Schirmer, no correlation } \\
\text { with levels of } \mathrm{NO}_{2}\end{array}$ \\
\hline Malerbi ${ }^{(64)}$ & 2012 & Series of cases & Sao Paulo, Brazil & & Meibomian gland evaluation & $\begin{array}{l}\text { Increased incidence of blepharitis in } \\
\text { high levels of } \mathrm{NO}_{2}\end{array}$ \\
\hline
\end{tabular}

a greater frequency of lower ST values and TFBUT values in hospital workers more exposed to traffic derived air pollution ${ }^{(43)}$.

In Italy, patients who presented to an ophthalmological emergency unit with "eye discomfort," reduced ST values and tear film instability were evaluated during the periods of acute rise in air pollution levels, summer and winter. Road traffic, heating system usage, and photochemical smog levels were reported as the main causes of their symptoms. Subjective symptoms were ocular irritation, such as heavy or tired eyes, foreign body sensation, burning, stinging, and photophobia. Also, impression cytology findings in six areas of bulbar and tarsal conjunctiva were altered in $69 \%$ of the subjects-49\% presented an early loss of goblet cells, $15 \%$ showed a total loss of goblet cells without keratinization, and $5 \%$ had a total loss of goblet cells with mild keratinization. Women showed higher frequency of symptoms that include ST<10 mm, and higher impression cytology score. In those subjects who lived in more polluted areas (urbanized compared to rural areas), impression cytology documented a greater frequency of keratinization and higher numbers of inflammatory cells (mainly mononuclear cells) in conjunctival scraping scores ${ }^{(44)}$.

Exposure to $\mathrm{NO}_{2}$, traffic derived air pollutant, and ocular surface changes were studied in volunteers in Sao Paulo, Brazil, the largest city in Latin America, and compared with individuals from a countryside area. The individuals living in Sao Paulo showed high levels of $\mathrm{NO}_{2}$ exposure and displayed goblet cell hyperplasia as a result of the chronic insult ${ }^{(8)}$. The same research group analyzed 55 cases of $\mathrm{NO}_{2}$ exposure and found that there is a dose-response relationship between incidence of symptoms and higher prevalence of meibomian gland dysfunction. However, there was a weak negative association with TFBUT and no correlation with ST values ${ }^{(41)}$. Recently another study demonstrated that exposure to high levels of air pollutants canlead to eyelid margin alterations ${ }^{(64)}$. The series of studies on the effects of air pollution on EDED in Brazil were innovative. The pollutant levels were individually measured with portable filter paper for a period of time rather than using broad environmental indices. Together, these findings suggest that life in large and polluted cities cause increased exposure of risk factors toward EDED.

Ultraviolet (UV) radiation is a common risk factor to ocular surface health for unprotected outdoor workers. For instance, climatic droplet keratopathy has been described and correlated with UV exposure ${ }^{(65)}$. Excess exposure to UV has been considered to result in acute tear film instability and induce transitory EDED, however, the reports are contradictory. Not enough evidence is currently available to indicate UV is a risk factor for EDED ${ }^{(66-68)}$. On the other hand, it has been well established that UV is one of the major risk factors in pterygium, a degenerative condition of the ocular surface resulting tear film instability. However, a cause and effect relationship still needs to be determined ${ }^{(69,70)}$

A large-scale study in Indonesia had shown that agricultural work is not a risk factor for EDED. Type of agricultural activities, amount, and time of exposures, climatic, chemical, and other environmental conditions need to be controlled in future studies to better understand their contributions as possible risk factors. Such an assessment entails delineating involvement of pesticides, fire, and UV irradiation ${ }^{(70)}$.

Indoor environmental contamination also has adverse health effects. The factors are lumped together into a group of signs and symptoms named the "Sick Building Syndrome" (SBS). In the last few decades the symptoms were described in workers in poorly ventilated office buildings. SBS includes non-specific ocular, nose and throat irritation, headache, and respiratory symptoms. Emission of the volatile organic compounds (VOCs) from the synthetic materials used in homes and offices together with other micro environmental variables such as temperature, humidity, lighting and airborne substances can also contribute to EDED. They can cause ocular symptoms, tear film instability, and alterations in ocular surface characteristics of EDED ${ }^{(40,62,71-74)}$. In 1992, Norn described that "sick building" workers have "pollution keratoconjunctivitis" with decline in BUT values and epithelial alterations detected by lissamine green staining ${ }^{(31)}$.

The broad ranges of environmental factors in office ambience associated with the demanding video display unit disrupt ocular surface homeostasis ${ }^{(4,30)}$. In epidemiologic and clinical studies it is important to consider the weight of confounding or summing factors such as allergic conjunctivitis, certain oral medications, BAK preservative eye drops, eye make up, blinking frequency, and contact lens wear.

The prevalence of indoor EDED can be estimated based on ocular discomfort complaints by office building workers. Based on the studies performed using questionnaires, it ranges from 5\%-40\% ${ }^{(62,75)}$. This large range may be due to the design of questionnaire, types of reported symptoms, inclusion of confounding variables that include contact lens wear, medications, and differences in recall periods. For instance, in 56 European buildings across 9 countries, 39\% of the individuals showed the mean prevalence of dry eye symptoms ${ }^{(76)}$. 
The anterior ocular surface forms a mucosal interface with large area continuously exposed to the environment. Comfort, proper visual acuity, and cellular maintenance are guaranteed by complex and harmonic interactions of epithelial cells and accessory glands and tear film compounds. Since the anterior ocular surface is the most densely innervated area of the body ${ }^{(77)}$, it is very sensitive to irritants and adverse environmental conditions (Figure 3).

Receptor-induced events that mediate signaling pathway of inflammatory responses resulting EDED symptoms such as decline in tear volume and altered composition are not completely understood. The following questions are need to be answered: to what extent the ocular surface discriminates different types of hazards? What makes the transition between an early/reactive phase to a chronic/ adaptive phase?

Environmental injury might induce increasing expression of cytokines, growth factors and other molecules that mediate specific signaling pathways, and corneal inflammatory and allergic response. During acute and chronic phases, specific cell types, inflammatory mediators, and neurotransmitters are involved ${ }^{(78)}$. Such responses vary depending on the nature and intensity of the stimulus and some mediators have been pointed as major contributors in the process of ocular surface damage related to environmental factors. Members of the transient receptor potential (TRP) channel superfamily, which include subfamilies in corneal epithelial and keratocytes, respond to environmental irritants inducing afferent impulses to the central nervous system ${ }^{(79)}$. Chemical burns in mice induce a specific TRP vanilloid type 1 (TRPV1) channel deregulated inflammatory responses leading to corneal melt and opacification ${ }^{(80)}$. The injury-induced inflammatory and opacification responses resulting from TRPV1 activation were attributed to the up regulation of pro inflammatory and chemo attractive cytokines. TRPV1-induces downstream events by eliciting time dependent stimulation of the mitogen activated protein kinase (MAPK) cascade in epithelial cells and stromal fibroblasts ${ }^{(79,81)}$. Corneal epithelial wound is also accompanied by increased release of mitogens such as, epidermal growth factor (EGF), which induces cell proliferation and migration through activation of a TRP channel in the canonical subfamily identified as TRPC4 and MAPK signaling pathway ${ }^{(82-85)}$.

Flow cytometry analysis of the tear fluid collected from the individuals with atopic keratoconjunctivitis after a conjunctival allergen provocation test presented higher levels of interferon-gamma, IL-6, and a borderline increase in IL-10 after 48 hours. There was a significant difference between provoked and unprovoked eye for the same cytokines: IL-6, IFNY, and IL-10 ${ }^{(86)}$. We speculate that individuals exposed to air pollution or other hazardous stimuli can elicit the similar inflammatory cascade during acute phase and lead to EDED clinical presentation, similar to other ocular surface inflammatory diseases, such as $A K C^{(78)}$.

Goblet cell hyperplasia results from exposure to high levels of air pollution in the urban population ${ }^{(8)}$. This is due to chronic exposure to air pollution by human nasal and respiratory mucosal surfaces that are considerably similar to conjunctiva ${ }^{(84,87-89)}$. However, studies in mice exposed to a desiccating environment showed the opposite response. The differences between the human and mouse may be explained by species-specific responses, complexity of the trigger (humans are frequently exposed to combined factors, such as pollutants and adverse climate), and/or observations collected at different time-points in the disease progression of both the species.

In vitro models are useful to simulate hazardous conditions and assess their effects on the ocular surface at the molecular level. In this regard, the observation that particulate pollutants disrupt meibomian gland lipid structure and consequently the tear film organization was reproduced using benzalkonium chloride (BAK) and quartz particles ${ }^{(90)}$. This study suggested that BAK affects the surface activity of meibomian lipids and quartz particles adsorbed to meibomian lipids, by removing them from the air/water interface. The authors proposed that a similar mechanism accounts for the effect of particulate pollutants on the tear film lipid layer ${ }^{(90)}$

The possibility of measuring specific effects of air pollutants and exposure to other environmental hazards on ocular surface integrity and health will identify the individuals with pathologic correlations to EDED. A recently described method is proven to be useful for this purpose. It comprises a filter paper in a small chamber attached to a belt or other piece of clothing (Figure 4). Air pollutants deposited on filters after different times were eluted and measured ${ }^{(41)}$. In this direction, a better understanding of EDED inducing factors and underlying mechanisms can be achieved. Such insights will help the development of more efficient preventive and therapeutic strategies.

\section{ENVIRONMENT MONITORING TOOLS}

The environment is being polluted by industrial waste, automobile and truck exhaust fumes, burning of coal and fossil fuels as well as chemical manufacturing. Air pollution can even come from smallscale every day indoor activities, such as dry cleaning, degreasing, and painting. These activities accumulate gases and particles that come incontact with our mucosal tissues, especially the anterior ocular surface.

There is an increasing demand for environmental health indicators capable of measuring the amount of chemical, climatic, and physical hazards. Since 1987, World Health Organization (WHO) published guidelines for air quality are reviewed periodically ${ }^{(91,92)}$. Similar guidelines, some with differences in items monitored or cut-off levels are provided by the Environmental Protection Agency (EPA) from the USA and other national or continental agencies (Table 5).

Among outdoor environmental parameters, climatic variables including temperature, atmospheric precipitation, humidity and UV radiation, and air pollutants including particulate matter (PM), $\mathrm{CO}_{2}, \mathrm{NO}_{2}, \mathrm{O}_{3}$ and $\mathrm{SO}_{2}$ were correlated with ocular and systemic diseases ${ }^{(92-94)}$. As mentioned above, the indoor pollutants are same as the more commonly monitored climatic parameters and they include include pollen, tobacco

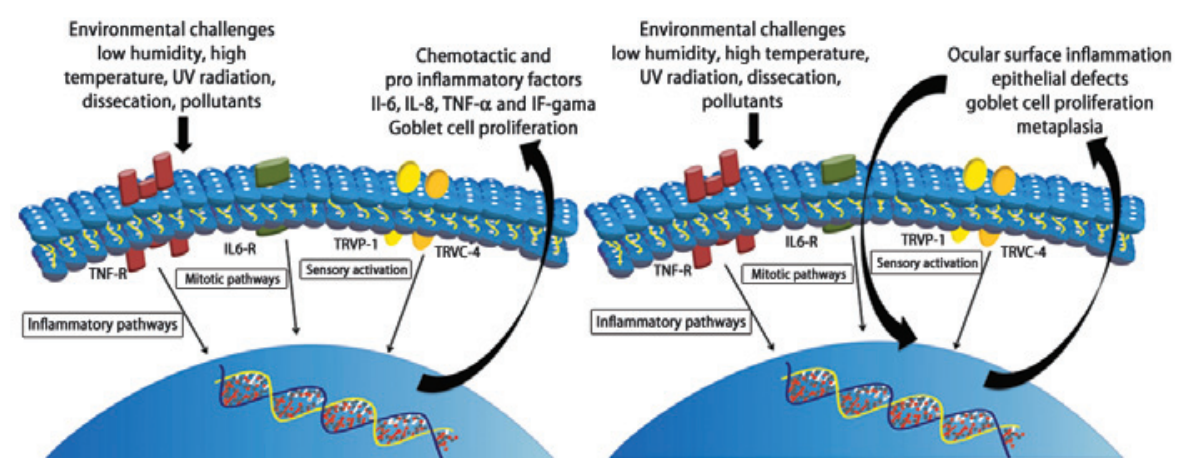

Figure 3. Illustrative steps of pathophysiological mechanisms in the acute phase of EDED at the cellular level. 

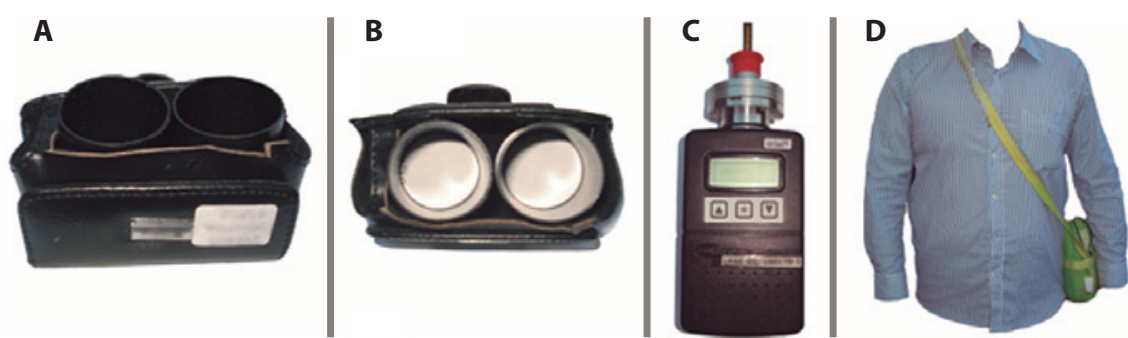

Figure 4. A) Double passive $\mathrm{NO}_{2}$ sampler containing a cellulose filter (Energetica, Rio de Janeiro, Brazil) impregnated with an absorbent solution of $2 \%$ triethanolamine, $0.05 \%$ o-methoxyphenol, and $0.025 \%$ sodium metabisulfite inside a small plastic tube with one of its extremities open to ambient air. The nitrite produced during sampling is determined colorimetrically by reacting the with sulfanilamide and 8-anilino-1-naphthalene-sulfonic acid (ANSA) and monitoring the absorption at $550 \mathrm{~nm}$ wavelength; B) Superior view of the $\mathrm{NO}_{2}$ sampler; C) Portable gravimetric impactor with a flow rate of $1.8 \mathrm{~L} / \mathrm{min}$. Air is aspirated into the impactor by a pump, $\mathrm{PM}$ is retained by a filter, and the particles in suspension in the air are measured gravimetrically; D) Portable sampler carried in a small bag by a research subject.

Table 5. Websites of agencies that provide guidelines and databases related to the environmental parameters in different regions of the world

\begin{tabular}{|c|c|c|}
\hline Agency & Website & Country/area \\
\hline European Space Agency & http://www.earthobservations.org/geoss_cl_ph.shtml & Global \\
\hline United Nation Economic Commission for Europe & http://www.unece.org/env/europe/monitoring/iandr_en.html & Global \\
\hline World Health Organization & http://www.who.int/ipcs/publications/ehc/ehc_numerical/en/index.html & Global \\
\hline Environmental Protection Agency & http://www.epa.gov/oaqps001/montring.html & USA \\
\hline Health Canada & http://www.hc-sc.gc.ca/ewh-semt/air/in/res-in/index-eng.php & Canada \\
\hline Instituto Nacional de Metereologia do Brasil & http://www.inmet.gov.br/portal/ & Brazil \\
\hline Companhia Ambiental do Estado de São Paulo & http://www.cetesb.sp.gov.br/ & São Paulo State, Brazil \\
\hline Ministry of the Environment Government of Japan & http://www.env.go.jp/en/ & Japan \\
\hline Ministry of Environmental Protection & http://english.mep.gov.cn/ & China \\
\hline $\begin{array}{l}\text { Department of Sustainability, Environment, Water, Population } \\
\text { and Communities }\end{array}$ & http://www.environment.gov.au/ & Australia \\
\hline Environment Agency & http://www.environment-agency.gov.uk/ & United Kingdom \\
\hline
\end{tabular}

smoke elements, mold, pesticides, carbon monoxide, formaldehyde, and lead among others ${ }^{(95)}$.

Those indicators are also monitored by national and international health and/or environmental agencies. They are then applied in health analysis studies to correlate diseases with epidemiology, governmental policy directives, and economic studies ${ }^{(12,96,97)}$.

This approach supports analysis of the health status of individuals or groups exposed to the above-indicated environmental risk factors. The results guide public health policies and preventive care ${ }^{(94,98-100)}$. They also help comparing environmental hazards in different areas or countries to promote actions that may reduce their effects ${ }^{(101)}$.

The information collected by the international or governmental agencies are available for public consulting ${ }^{(102)}$. These agencies work together to adopt similar measurement standards, units, and methods, and make the data available to the public through web databases and annual publications ${ }^{(91)}$.

Data on air quality or climate could be used to correlate with clinical observations of incidences of EDED in different cities or regions. However, the daily range of pollutants, hazardous agents, confounding factors, and individual variable time-exposure to any of the studied agents can be too large to precisely identify agents responsible for higher EDED incidence in a certain area. These limitations may make it difficult to draw meaningful conclusions. To avoid that, study designs are required to include homogeneous groups with similar habits and comparable exposure times. One report had described that children living close to three petrochemical companies in Nigeria have tetraethyl lead and black carbon tear film ${ }^{(29)}$. Similar studies are necessary to identify the specific pollutants responsible for a cause and effect relationship between an environmental factor and EDED.

\section{CONCLUSIONS}

For several years, environmental factors have been known to be associated with DED. A more extensive and detailed analysis of the association between environmental factors and DED suggest that EDED as a DED subtype will aid efforts to pinpoint different factors responsible for this disease. To this end, we propose that combined clinical and laboratory studies can help identify different environmental factors that induce EDED. At this point, we were able to summarize evidence supporting the association of specific environmental hazards such as pollutants and adverse outdoor and indoor environmental factors with EDED.

DED clinical findings and symptoms resulting from environmental factor mediated anterior ocular surface receptor activation induce pro inflammatory cytokines, chemo attractant expression, and elaboration of extracellular stromal matrix due to increases in myofibroblast expression. These mechanisms induce tear film instability, stromal immune cell infiltration, and disruption of lacrimal gland mediated tear film volume and composition. Constant exposure to environmental factors may allow the clinician to distinguish between acute and a chronic phase of the disease.

Environmental data monitoring and safety limits obtained from international or governmental agencies may help clinicians to associate DED disease stages with environmental factor exposure. Researchers may be aided in identifying relevant stress to apply to their different model systems to pinpoint the mechanisms mediating responses underlying EDED.

Unfortunately, except for using protective equipment to counter specific hazardous environmental agent stresses, EDED treatment is limited to the same medications and interventions available for other 
types of DED. ${ }^{(103)}$ Given this limitation, it remains important to promote novel investigative interventions to treat or minimize EDED damage.

\section{ACKNOWLEDGEMENT}

This study was supported by grants from the following Brazilian governmental agencies: "Fundação de Amparo a Pesquisa do Estado de São Paulo" (FAPESP), "Conselho Nacional de Desenvolvimento Científico e Tecnológico" (CNPq), "Fundação de Apoio ao Ensino, Pesquisa e Assistência do Hospital das Clinicas da Faculdade de Medicina de Ribeirão Preto da Universidade de São Paulo" (FAEPA), and "Núcleo de Apoio a Pesquisa - Fisiopatologia e Terapêutica Ocular (NAP-FTO) da Universidade de São Paulo."

The authors would like to acknowledge Maria Helena Andrade and Andre Torricelli for their contribution to this study.

\section{REFERENCES}

1. Moss SE, Klein R, Klein BE. Prevalence of and risk factors for dry eye syndrome. Arch Ophthalmol. 2000;118(9):1264-8.

2. Moss SE, Klein R, Klein BE. Incidence of dry eye in an older population. Arch Ophthalmol. 2004;122(3):369-3

3. The epidemiology of dry eye disease: report of the Epidemiology Subcommittee of the International Dry Eye WorkShop. Ocul Surf. 2007;5(2):93-107.

4. Wolkoff $P$, Skov P, Franck $C$, Petersen LN. Eye irritation and environmental factors in the office environment-hypotheses, causes and a physiological model. Scand J Work Environ Health. 2003;29(6):411-30

5. Iyer JV, Lee SY, Tong L. The dry eye disease activity log study. Scientific World Journal. 2012;2012:589875

6. Wong J, Lan W, Ong LM, Tong L. Non-hormonal systemic medications and dry eye. Ocul Surf. 2011;9(4):212-6.

7. Kim JH, Nam WH, Yi K, Choi DG, Hyon JY, Wee WR, Shin YJ. Oral alcohol administration disturbs tear film and ocular surface. Ophthalmology. 2012;119(5):965-1.

8. Novaes P, do Nascimento Saldiva PH, Kara-Jose N, Macchione M, Matsuda M, Racca $L$, et al. Ambient levels of air pollution induce goblet-cell hyperplasia in human conjunctival epithelium. Environ Health Perspect. 2007;115(12):1753-6.

9. Moen BE, Norbäck D, Wieslander G, Bakke JV, Magerøy N, Granslo JT, et al. Can air pollution affect tear film stability? A cross-sectional study in the aftermath of an explosion accident. BMC Public Health. 2011;11:235.

10. Friedlaender MH. Ocular allergy. Curr Opin Allergy Clin Immunol. 2011;11(5): 477-82

11. Bron AJ, Daubas P, Siou-Mermet R, Trinquand C. Comparison of the efficacy and safety of two eye gels in the treatment of dry eyes: Lacrinorm and Viscotears. Eye (Lond). 1998;12 (Pt 5):839-47.

12. Saldiva PH, Pope CA, 3rd, Schwartz J, Dockery DW, Lichtenfels AJ, Salge JM, Barone I, Bohm GM. Air pollution and mortality in elderly people: a time-series study in Sao Paulo, Brazil. Arch Environ Health. 1995;50(2):159-63.

13. Barabino S, Dana MR. Animal models of dry eye: a critical assessment of opportunities and limitations. Invest Ophthalmol Vis Sci. 2004;45(6):1641-6.

14. Nakamura S, Shibuya M, Nakashima H, Hisamura R, Masuda N, Imagawa T, et al. Involvement of oxidative stress on corneal epithelial alterations in a blink-suppressed dry eye. Invest Ophthalmol Vis Sci. 2007:48(4):1552-8.

15. Stern ME, Schaumburg CS, Siemasko KF, Gao J, Wheeler LA, Grupe DA, et al. Autoantibodies contribute to the immunopathogenesis of experimental dry eye disease. Invest Ophthalmol Vis Sci. 2012;53(4):2062-75.

16. Chen Z, Li Z, Basti S, Farley WJ, Pflugfelder SC. Altered morphology and function of the lacrimal functional unit in protein kinase C\{alpha\} knockout mice. Invest Ophthalmol Vis Sci. 2010;51(11):5592-600.

17. Brown-Grant K, Tata J. The distribution and metabolism of thyroxine and 3:5:3'-triiodothyronine in the rabbit. J Physiol. 1961;157(1):157-76.

18. The definition and classification of dry eye disease: report of the Definition and Classification Subcommittee of the International Dry Eye WorkShop (2007). Ocul Surf. 2007;5(2):75-92.

19. Cullen AP. Photokeratitis and other phototoxic effects on the cornea and conjunctiva. Int J Toxicol. 2002;21(6):455-4

20. Utine CA, Bicakcigil M, Yavuz S, Ciftci F. Tear osmolarity measurements in dry eye related to primary Sjogren's syndrome. Curr Eye Res. 2011;36(8):683-90.

21. De PK, Banerjee R. Identification, properties and effect of hormones on rat preputial gland peroxidase. J Endocrinol. 1987;112(2):239-45

22. Derocq JM, Jbilo O, Bouaboula M, Ségui M, Clère C, Casellas P. Genomic and functional changes induced by the activation of the peripheral cannabinoid receptor CB2 in the promyelocytic cells HL-60. Possible involvement of the CB2 receptor in cell differentiation. J Biol Chem. 2000;275(21):15621-8.
23. Deshmukh PK, Gattani SG. In vitro and in vivo consideration of novel environmentally responsive ophthalmic drug delivery system. Pharm Dev Technol. 2013;18(4):950-6.

24. Ding $\mathrm{CH}$, Wang XH, Zou LP, Lü JL, Wu HS, Wu Y, et al. [Clinical characteristics and diagnosis of acute pandysautonomia in childhood]. Zhonghua Er Ke Za Zhi. 2010;48(6): 454-9. Chinese.

25. Doerge D. Mechanism-based inhibition of lactoperoxidase by thiocarbamide goitrogens. Biochemistry. 1986;25(16):4724-8.

26. Dolgin E. In Brazil, basic stem cell research lags behind clinical trials. Nat Med. 2011; 17(10):1172.

27. Drouault-Holowacz S, Bieuvelet S, Burckel A, Rigal D, Dubray C, Lichon J, et al. Antioxidants intake and dry eye syndrome: a crossover, placebo-controlled, randomized trial. Eur J Ophthalmol. 2009;19(3):337-42.

28. Dvorscak L, Marfurt CF. Age-related changes in rat corneal epithelial nerve density. Invest Ophthalmol Vis Sci. 2008:49(3):910-6.

29. Asonye CC, Bello ER. The blight of pollution keratoconjunctivitis among children in oil-producing industrial areas of Delta State, Nigeria. Ecotoxicol Environ Saf. 2004; 59(2):244-8.

30. Blehm C, Vishnu S, Khattak A, Mitra S, Yee RW. Computer vision syndrome: a review. Surv Ophthalmol. 2005;50(3):253-62.

31. Norn M. Pollution keratoconjunctivitis. A review. Acta Ophthalmol (Copenh). 1992; 70(2):269-73.

32. Levy Jl, Clougherty JE, Baxter LK, Houseman EA, Paciorek CJ; HEl Health Review Committee. Evaluating heterogeneity in indoor and outdoor air pollution using land-use regression and constrained factor analysis. Res Rep Health Eff Inst. 2010(152):5-80; discussion 81-91.

33. Levy Jl, Hanna SR. Spatial and temporal variability in urban fine particulate matter concentrations. Environ Pollut. 2011;159(8-9):2009-15.

34. Basu PK. Air pollution and the eye. Surv Ophthalmol. 1972;17(2):78-93.

35. Schiffman RM, Christianson MD, Jacobsen G, Hirsch JD, Reis BL. Reliability and validity of the Ocular Surface Disease Index. Arch Ophthalmol. 2000;118(5):615-21.

36. Zhang $X$, Chen $Q$, Chen W, Cui L, Ma H, Lu F. Tear dynamics and corneal confocal microscopy of subjects with mild self-reported office dry eye. Ophthalmology. 2011; 118(5):902-7.

37. Torricelli AA, Novaes P, Matsuda M, Braga A, Saldiva PH, Alves MR, et al. Correlation between signs and symptoms of ocular surface dysfunction and tear osmolarity with ambient levels of air pollution in a large metropolitan area. Cornea. 2012;32(4):e11-15.

38. Hempel-Jorgensen A, Kjaergaard SK, Molhave L. Cytological changes and conjunctival hyperemia in relation to sensory eye irritation. International Arch Occup and Environ Health. 1998;71(4):225-35.

39. Walker JC, Kendal-Reed M, Utell MJ, Cain WS. Human breathing and eye blink rate responses to airborne chemicals. Environ Health Perspect. 2001;109 Suppl 4:507-12.

40. Franck C, Bach E, Skov P. Prevalence of objective eye manifestations in people working in office buildings with different prevalences of the sick building syndrome compared with the general population. Int Arch Occup Environ Health. 1993;65(1):65-69.

41. Novaes P, Saldiva PH, Matsuda M, Macchione M, Rangel MP, Kara-Jose N, et al. The effects of chronic exposure to traffic derived air pollution on the ocular surface. Environ Res. 2010;110(4):372-4.

42. Moen BE, Norback D, Wieslander G, Bakke JV, Mageroy N, Granslo JT, et al. Can air pollution affect tear film stability? A cross-sectional study in the aftermath of an explosion accident. BMC Public Health. 2011;11:235.

43. Saxena R, Srivastava S, Trivedi D, Anand E, Joshi S, Gupta SK. Impact of environmental pollution on the eye. Acta Ophthalmol Scand. 2003;81(5):491-4.

44. Versura P, Profazio V, Cellini M, Torreggiani A, Caramazza R. Eye discomfort and air pollution. Ophthalmologica. 1999:213(2):103-9.

45. Dalfré JT, Rodrigues JP, Donato BG, Giancoli Neto A, de Carvalho JL, de Andrade Oliveira Dl, et al. [Fungic microbiota of normal conjunctiva, sugar-cane and anemophilous fungi of the region of Monte Belo - Minas Gerais]. Arq Bras Oftalmol. 2007;70(3):445-9. Portuguese

46. Torricelli AA, Novaes P, Matsuda M, Alves MR, Monteiro ML. Ocular surface adverse effects of ambient levels of air pollution. Arq Bras Oftalmol. 2011:74(5):377-81.

47. Tsai DH, Lin JS, Chan CC. Office workers' sick building syndrome and indoor carbon dioxide concentrations. J Occup Environ Hyg. 2012;9(5):345-51.

48. Wolkoff P, Kärcher T, Mayer H. Problems of the "outer eyes" in the office environment: an ergophthalmologic approach. J Occup Environ Med. 2012;54(5):621-31.

49. Skyberg K, Skulberg KR, Eduard W, Skaret E, Levy F, Kjuus H. Symptoms prevalence among office employees and associations to building characteristics. Indoor air. 2003; 13(3):246-52.

50. Yang CY, Wang JD, Chan CC, Chen PC, Huang JS, Cheng MF. Respiratory and irritant health effects of a population living in a petrochemical-polluted area in Taiwan. Environ Research. 1997;74(2):145-9.

51. The epidemiology of dry eye disease: report of the Epidemiology Subcommittee of the International Dry Eye WorkShop (2007). Ocul Surf. 2007;5(2):93-107.

52. Baiz N, Slama R, Bene MC, Charles MA, Kolopp-Sarda MN, Magnan A, et al. Maternal exposure to air pollution before and during pregnancy related to changes in newborn's cord blood lymphocyte subpopulations. The EDEN study cohort. BMC Pregnancy Childbirth. 2011;11:87.

53. Kojima T, Ibrahim OM, Wakamatsu T, Tsuyama A, Ogawa J, Matsumoto Y, et al. The impact of contact lens wear and visual display terminal work on ocular surface and tear functions in office workers. Am J Ophthalmol. 2011;152(6):933-940.e932. 
54. Design and conduct of clinical trials: report of the Clinical Trials Subcommittee of the International Dry Eye WorkShop (2007). Ocul Surf. 2007;5(2):153-62.

55. Riediker M, Monn C, Koller T, Stahel WA, Wuthrich B. Air pollutants enhance rhinoconjunctivitis symptoms in pollen-allergic individuals. Ann Allergy Asthma Immunol. 2001;87(4):311-8

56. Ritz SA. Air pollution as a potential contributor to the'epidemic' of autoimmune disease. Med Hypotheses. 2010;74(1):110-7.

57. Bernatsky S, Fournier M, Pineau CA, Clarke AE, Vinet E, Smargiassi A. Associations between ambient fine particulate levels and disease activity in patients with systemic lupus erythematosus (SLE). Environ Health Perspect. 2011;119(1):45-9.

58. Hart JE, Laden F, Puett RC, Costenbader KH, Karlson EW. Exposure to traffic pollution and increased risk of rheumatoid arthritis. Environ Health Perspect. 2009:117(7):1065-9.

59. Leonardi A, Lanier B. Urban eye allergy syndrome: a new clinical entity? Curr Medical Res Opin. 2008;24(8):2295-302.

60. Kjaergaard SK, Pedersen OF. Dust exposure, eye redness, eye cytology and mucous membrane irritation in a tobacco industry. Int Arch Occup Environ Health. 1989;61 (8): 519-25.

61. Paschides CA, Stefaniotou M, Papageorgiou J, Skourtis P, Psilas K. Ocular surface and environmental changes. Acta Ophthalmol Scand. 1998;76(1):74-7.

62. Wolkoff P, Nojgaard JK, Franck C, Skov P. The modern office environment desiccates the eyes? Indoor Air. 2006;16(4):258-65.

63. Gupta SK, Gupta V, Joshi S, Tandon R. Subclinically dry eyes in urban Delhi: an impact of air pollution? Ophthalmologica. 2002;216(5):368-71.

64. Malerbi FK, Martins LC, Saldiva PH, Braga AL. Ambient levels of air pollution induce clinical worsening of blepharitis. Environ Res. 2012;112:199-203.

65. Burgess PI, Koay P, Clark P. SmartPlug versus silicone punctal plug therapy for dry eye: a prospective randomized trial. Cornea. 2008;27(4):391-4.

66. Capobianco KG, Xavier RM, Bredemeier M, RestelliVG, Brenol JC. Nailfold capillaroscopic findings in primary Sjögren's syndrome: clinical and serological correlations. Clin Exp Rheumatol. 2005;23(6):789-94

67. Dawson L, Field E, Harmer A, Smith P. Acetylcholine-evoked calcium mobilization and ion channel activation in human labial gland acinar cells from patients with primary Sjögren's syndrome. Clin Exp Immunol. 2001;124(3):480-5.

68. Feretis E, Theodorakopoulos P,Varotsos C, Efstathiou M, Tzanis C, Xirou T et al. On the plausible association between environmental conditions and human eye damage. Environ Scie Pollut Res Int. 2002:9(3):163-5

69. de Souza G, Godoy L, Mann M. Identification of 491 proteins in the tear fluid proteome reveals a large number of proteases and protease inhibitors. Genome Biol. 2006;7(8):R72.

70. Lee AJ, Lee J, Saw SM, Gazzard G, Koh D, Widjaja D, et al. Prevalence and risk factors associated with dry eye symptoms: a population based study in Indonesia. $\mathrm{Br} J$ Ophthalmol. 2002:86(12):1347-51.

71. Koren HS, Graham DE, Devlin RB. Exposure of humans to a volatile organic mixture. III. Inflammatory response. Arch Environ Health. 1992;47(1):39-44.

72. Nordstrom K, Norback D, Akselsson R. Influence of indoor air quality and personal factors on the sick building syndrome (SBS) in Swedish geriatric hospitals. Occup Environ Med. 1995;52(3):170-6.

73. Wieslander G, Norback D, Nordstrom K, Walinder R, Venge P. Nasal and ocular symptoms, tear film stability and biomarkers in nasal lavage, in relation to building-dampness and building design in hospitals. Int Arch Occup Environ Health. 1999:72(7):451-61.

74. Schneider T, Sundell J, Bischof W, Bohgard M, Cherrie JW, Clausen PA, et al. 'EUROPART'. Airborne particles in the indoor environment. A European interdisciplinary review of scientific evidence on associations between exposure to particles in buildings and health effects. Indoor Air. 2003;13(1):38-48.

75. Skov P, Valbjorn O, Pedersen BV. Influence of personal characteristics, job-related factors and psychosocial factors on the sick building syndrome. Danish Indoor Climate Study Group. Scand J Work Environ Health. 1989;15(4):286-95.

76. Bluyssen PM, De Oliveira Fernandes E, Gores L, Claussen G. Fanger PO, Valbjorn O, et al. European indoor air quality audit project in 56 office buildings. Indoor Air. 1996;6: (4) $221-38$

77. Edelhauser HF, Van Horn DL, Records RE. Cornea and sclera. In: Duane TD, Jaeger EA, editors. Biomedical Foundations of Ophthalmology. Philadelphia, PE: Harper\&Row Publishers; 1982. Vol.2. p.1-26.

78. McDermott AM, Perez V, Huang AJ, Pflugfelder SC, Stern ME, Baudouin C, et al.
Pathways of corneal and ocular surface inflammation: a perspective from the cullen symposium. Ocul Surf. 2005:3(4 Suppl):S131-8.

79. Zhang F, Yang H, Wang Z, Mergler S, Liu H, Kawakita T, et al. Transient receptor potential vanilloid 1 activation induces inflammatory cytokine release in corneal epithelium through MAPK signaling. J Cell Physiol. 2007;213(3):730-9.

80. Okada Y, Reinach PS, Shirai K, Kitano A, Kao WW, Flanders KC, et al. TRPV1 involvement in inflammatory tissue fibrosis in mice. Am J Pathol. 2011;178(6):2654-64.

81. Yang Y, Yang H, Wang Z, Mergler S, Wolosin JM, Reinach PS. Functional TRPV1 expression in human corneal fibroblasts. Exp Eye Res. 2013;107:121-9.

82. Pan Z, Wang Z, Yang H, Zhang F, Reinach PS. TRPV1 activation is required for hypertonicity-stimulated inflammatory cytokine release in human corneal epithelial cells. Invest Ophthalmol Vis Sci. 2011;52(1):485-93

83. Yang H, Mergler S, Sun X, Wang Z, Lu L, Bonanno JA, et al. TRPC4 knockdown suppresses epidermal growth factor-induced store-operated channel activation and growth in human corneal epithelial cells. J Biol Chem. 2005;280(37):32230-7.

84. Corrales RM, de Paiva CS, Li DQ, Farley WJ, Henriksson JT, Bergmanson JP, et al Entrapment of conjunctival goblet cells by desiccation-induced cornification. Invest Ophthalmol Vis Sci. 2011;52(6):3492-9.

85. Zheng X, de Paiva CS, Li DQ, Farley WJ, Pflugfelder SC. Desiccating stress promotion of Th17 differentiation by ocular surface tissues through a dendritic cell-mediated pathway. Invest Ophthalmol Vis Sci. 2010;51(6):3083-91.

86. Nivenius E, Van der Ploeg I, Gafvelin G, Van Hage M, Montan PG. Conjunctival provocation with airborne allergen in patients with atopic keratoconjunctivitis. Clin Exp Allergy. 2012:42(1):58-65.

87. Saldiva PH, King M, Delmonte VL, Macchione M, Parada MA, Daliberto ML, et al. Respiratory alterations due to urban air pollution: an experimental study in rats. Environ Res. 1992;57(1):19-33.

88. Camargo Pires-Neto R, Julia Lichtenfels A, Regina Soares S, Macchione M, Hilario Nascimento Saldiva P, Dolhnikoff M. Effects of Sao Paulo air pollution on the upper airways of mice. Environ Res. 2006;101(3):356-61.

89. Dartt DA. Control of mucin production by ocular surface epithelial cells. Exp Eye Res 2004:78(2):173-85

90. Zhao J, Wollmer P. Air pollutants and tear film stability-a method for experimenta evaluation. Clin Physiol. 2001;21(3):282-6.

91. Vahlsing C, Smith KR. Global review of national ambient air quality standards for PM10 and SO2 (24 h). Air Qual Atmos Health. 2012;5(4):393-9.

92. WHO's global air-quality guidelines. Lancet. 2006;368(9544):1302.

93. McGeehin MA, Mirabelli M. The potential impacts of climate variability and change on temperature-related morbidity and mortality in the United States. Environ Health Perspect. 2001;109(Suppl 2):185-9.

94. Jerrett M, Burnett RT, Pope CA 3rd, Ito K, Thurston G, Krewski D, et al. Long-term ozone exposure and mortality. N Engl J Med. 2009;360(11):1085-95.

95. Hoppe P, Martinac I. Indoor climate and air quality. Review of current and future topics in the field of ISB study group 10. Int J Biometeorol. 1998;42(1):1-7.

96. Ibrahim MM, de Angelis R, Lima AS, Viana de Carvalho GD, Ibrahim FM, Malki LT, et al. A new method to predict the epidemiology of fungal keratitis by monitoring the sales distribution of antifungal eye drops in Brazil. PLoS One. 2012;7(3):e33775.

97. Thurston GD, Bekkedal MY, Roberts EM, Ito K, Pope CA 3rd, Glenn BS, et al. Use of health information in air pollution health research: past successes and emerging needs. J Expo Sci Environ Epidemiol. 2009;19(1):45-58.

98. Kan H, London SJ, Chen G, Zhang Y, Song G, Zhao N, et al. Season, sex, age, and education as modifiers of the effects of outdoor air pollution on daily mortality in Shanghai, China: The Public Health and Air Pollution in Asia (PAPA) Study. Environ Health Perspect. 2008;116(9):1183-8

99. Robins TG, Salie F, Gwagwa T. Occupational hazards, living conditions, and physical assault of sugar cane workers in KwaZulu-Natal, South Africa. S Afr Med J. 1998;88(9): 1117-27.

100. Gascon M, Kromhout H, Heederik D, Eduard W, van Wendel de Joode B. Respiratory, allergy and eye problems in bagasse-exposed sugar cane workers in Costa Rica. Occup Environ Med. 2012:69(5):331-8

101. Chen B, Kan H. Air pollution and population health: a global challenge. Environ Health Prev Med. 2008;13(2):94-101.

102. Tomlinson A, Madden LC, Simmons PA. Effectiveness of dry eye therapy under conditions of environmental stress. Curr Eye Res. 2013;38(2):229-36. 